\title{
Judicial Resolution of Inter-Agency Legal Disputes
}

Tradition has assigned to the President the task of settling disputes among departments and non-independent agencies of the executive branch. ${ }^{1}$ The complex regulatory duties that Congress gives to the executive branch create an inexhaustible source of legal conflicts ${ }^{2}$ among the agencies; ${ }^{3}$ the need for resolution by some external or superior authority is unquestionable. Yet the current practice of informal resolution of inter-agency legal disputes within the executive branch occasionally compromises the public interest.

This Note suggests that executive-branch departments and agencies should have an opportunity to litigate disputes about congres-

1. See Exec. Order No. 12,146, 44 Fed. Reg. 42,657 (1979) (đirecting intra-branch resolution of legal disputes among executive agencies). Regular adherence to the custom of resolving inter-agency legal conflicts within the executive branch, embodied in Exec. Order No. 12,146, has meant that questions about the justiciability of such disputes in federal court have seldom been forced on the present Administration. Interview with Leon Ulman, Deputy Assistant Attorney General, Office of Legal Counsel, U.S. Justice Department, in Washington, D.C. (Dec. 17, 1979) (notes on file with Yale Law Journal). Yet, in the only recent legal dispute among federal parties in which the agencies actually questioned whether they might litigate the issue rather than submit it to intra-branch arbitration, the Justice Department concluded that an inter-agency lawsuit was impossible. See Memorandum Opinion for the Acting Assistant Attorney General, Tax Division: Proposed Tax Assessment Against the United States Postal Service, I Opinions of the Office of Legal Counsed of the United States Department of Justice 79 (L. Ulman ed. 1980) (Opinion No. 77-22, dated Apr. 22, 1977) [hereinafter cited as .OLC 77-22].

References in this Note to "executive-branch" agencies, as opposed to "independent" agencies, rely on the traditional distinction between authorities whose leadership serves at the President's pleasure and those whose heads enjoy significantly independent tenure. See 1 K. Davis, Administrative Law Treatise $\$$ 2:7, at 85 (2d ed. 1978) (power of removal a "meaningful" test of agency status); $c f$. Exec. Order No. 12,146, § 1-4, 44 Fed. Reg. 42,657 (1979) (rule to govern procedures for resolution of inter-agency disputes distinguishing between "agencies whose heads serve at the pleasure of the President" and other authorities).

Comprehensive distinctions between the so-called independent agencies and the administrative bodies that are responsible to the President are elusive. See K. DAvis, supra, at 82-87 (summarizing various methods of classification). One attribute of the major independent agencies is a capacity to litigate against the Justice Department. See note 4 infra (cases establishing standing of independent agencies). Insofar as this Note's argument recommends that the executive-branch agencies should also possess a capacity to litigate, it would diminish the need for problematic distinctions among the fecleral regulatory authorities.

2. Conflicts concerning regulatory policy and other nonlegal issues are not within the scope of this Note. See Note, Delegation and Regulatory Reform: Letting the President Change the Rules, 89 YALE L.J. 561 (1980) (methods of resolving intra-branch policy debates).

3. See notes $6,7,8,16,25, \& 82$ infra (recent examples of serious inter-agency legal conflicts). 
sional allocations of regulatory power as principal and adverse parties in federal court. Inter-agency litigation would eliminate the practical inadequacies of the internal settlement process, and would conform to the constitutional and prudential limits on the federal judicial power.

\section{The Quest for Executive-Branch Unanimity}

Although politically autonomous bodies like the Interstate Commerce Commission have long been able to oppose the Justice Department in federal court, ${ }^{\ddagger}$ the cabinet-level departments and non-independent agencies have been assumed to have no such capacity to litigate..$^{5}$ Instead, the executive branch has developed informal arbitration processes to resolve serious inter-agency legal disputes generated by the statutory delegation of authority to the agencies. Even though an internal settlement concludes the dispute among the President's officers, that solution is often later subjected to judicial review at the suit of private parties. Such a pattern introduces substantial delays and uncertainties into the federal administrative process.

\section{A. The Sources of Intra-Branch Legal Disputes}

Many disputes within the executive branch turn upon the construction of statutes granting regulatory power to the agencies. ${ }^{6}$ The

4. See United States v. ICC, 337 U.S. 426 (1949) (permitting War Department, as shipper of freight, to sue Commission to set aside reparations order); $c f$. United States v. ICC, 396 U.S. 491 (1970) (Court deciding merits of Justice Department's attack on Commission's approval of railroad merger without questioning jurisdiction); FTC v. Ruberoid Co., 343 U.S. 470, 482 (1952) (Jackson, J., dissenting) (noting "recent instances in which part of the government appears before us fighting another part. . . .") But see United States v. Easement \& Right of Way, 204 F. Supp. 837, 839 (E.D. Tenn. 1962) (denying motion of Tennessee Valley Authority to join Farmers Home Administration, a division of Agriculture Department, as defendant in condemnation suit, "both [agencies] being the United States. . . ."); OLC 77-22, supra note 1, at 82-83 (Justice Department, although deeming Postal Service an independent agency, concluding the latter's dispute with Internal Revenue Service to be non-justiciable). One commentary has assumed the capacity of "one federal agency to sue another," see Comment, Municipal Corporation Standing to Sue the State: Rogers v. Brockette, 93 HARv. L. Rev. 586, 593 n.51 (1980), but its conclusion appears based only upon cases involving independent agencies. $I d$.

5. See note 1 supra (current Administration's presumption that inter-agency legal disputes cannot be litigated).

6. Occasionally, inter-agency legal disputes depend not upon language in statutes but upon construction of other instruments. Thus, in a dispute culminating in Pueblo of Taos v. Andrus, 475 F. Supp. 359 (D.D.C. 1979), the Agriculture and Interior Departments both possessed colorable claims, based on nineteenth-century deeds and surveys, to administer a tract of western land. The competing agencies obtained an opinion from the Attorney General that resolved the dispute by allotting management duties to an Agriculture Department agency, $i d$. at 362; subsequently, private parties successfully challenged the Attorney General's opinion in Pueblo of Taos. 
most serious problems of statutory interpretation typically assume two forms. Different statutes sometimes appear to assign exclusive regulatory power over a particular subject-matter to separate agencies. ${ }^{7}$ In other cases, statutes seem to grant one agency the power to supervise another agency's regulation of private-sector activities. ${ }^{8}$ Uncertainty about congressional intent in such matters is inevitable in the complex legislation that creates the agencies and establishes their regulatory programs. ${ }^{9}$

When neither agency will give up its claim to exclusive regulatory authority, or when the two agencies cannot agree on whether one agency is accountable to the other, uncertainty about the statutes'

7. An example is the dispute summarized in California v. Kleppe, 604 F.2d 1187 (9th Cir. 1979). The Environmental Protection Agency (EPA) differed with the view of the Interior Department that an amendment to the Outer Continental Shelf Lands Act, 43 U.S.C. $\$ 1334$ (a)(8) (Supp. II 1978), transferred exclusive power to promulgate federal air-emission control regulations from EPA to the Interior Secretary. The Justice Department agreed with EPA, see note 16 infra, and unsuccessfully argued EPA's position in the challenge to EPA authority in the California $v$. Kleppe suit commenced by state and industry parties.

8. A conflict between the Commerce and Interior Departments concerning Interior's supervision of offshore oil exploration pursuant to the Outer Continental Shelf Lands Act, 43 U.S.C. $\$ \S 1331-1356$ (1976 \& Supp. II 1978) (OCSLA) is typical of such disputes. Commerce asserted that Interior's leasing and "preleasing" activities affecting the coastal zone were subject to controls in the Coastal Zone Management Act, 16 U.S.C. $\$ \S 1451$ 1464 (1976 \& Supp. II 1978) (CZMA). Interior disagreed with Commerce's interpretations of OCSLA and CZMA. The two departments sought intra-branch arbitration of their dispute, and the Justice Department eventually issued an opinion letter accepting with some qualifications Commerce's view of the statutes that subordinated certain OCSLA functions to CZMA requirements. As a result, Interior's "preleasing" activities that directly affect the coastal zone must conform to state coastal management programs, pursuant to 16 U.S.C. $\$ 1456$ (c)(I) (1976 \& Supp. II 1978) (government activities "directly affecting the coastal zone" to be "consistent" with Commerce-approved state control plans). See Letter from Leon Ulman, Deputy Assistant Attorney General, to C.L. Haslam, Commerce Department, and Leo M. Krulitz, Interior Department (Apr. 20, 1979) (rendering Justice Department opinion) (copy on file with Yale Law Journal).

9. Current doctrine holds that, as a principle of statutory construction, contradictory assignments of regulatory jurisdiction are impossible. See, e.g., California v. Kleppe, 604 F.2d 1187, 1199 (9th Cir. 1979) ("N]o jurisdictional conflict can arise" because Congress cannot have intended that "the jurisdictional grants [to EPA and Interior] . . could stand together."); Get Oil Out! Inc. v. Exxon Corp., 586 F.2d 726, 729 (9th Cir. 1978) (where acts have potential for conflict, court's "obligation [is] to so construe federal statutes ... that they are consistent with each other," in order to vindicate congressional intent).

Foreclosure of inter-agency legal disputes through more precise drafting of regulatory statutes could never be complete. As in the Interior Department-Commerce Department conflict, see note 8 supra, it may be difficult for Congress to anticipate questions about statutory authority arising from details of agency procedures promulgated after passage of the statute. This is particularly true when more than one agency has general regulatory duties in the area that the statute addresses. Statutory attempts to consolidate regulatory power in a single executive-branch authority by amendments transferring that power from other agencies appear to be especially troublesome. See note 30 infra (agency uncertainty concerning possible transfers of function under Department of Energy Organization Act). 
requirements will lead to conflict. The questions raised in such disputes are essentially jurisdictional. ${ }^{10}$ The agencies do not clash on proper interpretation of the substantive guidelines Congress has established for use by some agency, but instead disagree on the threshold question of which agency has authority to act at all, or of whether one agency must supervise another's regulation.

\section{B. The Two-Step Resolution Process}

When a dispute within the executive branch is identified as legal in nature, ${ }^{11}$ the Justice Department may intervene, at the request of the White House, ${ }^{12}$ by formulating an opinion ${ }^{13}$ to settle the conflict. ${ }^{14}$ The contending agencies are expected to adopt the Justice De-

10. This Note deals with the resolution of these inter-agency disputes over jurisdiction. The proposal for litigation of inter-agency disputes thus does not extend to all disagreements within the executive branch concerning the interpretation of statutes or otherwise subject to classification as questions of law. The Interior Department-Commerce Department dispute, see note 8 supra, the Interior Department-EPA dispute, see note 7 supra, and the Interior Department-Agriculture Department dispute, see note 6 supra, are all examples of "jurisdictional" disputes. Because all the agencies agree on which executivebranch authorities have the power to promulgate rules, however, the dispute concerning implementation of civil rights legislation, see note 27 infra, is not a dispute over jurisdiction; there, the agencies cannot agree on substantive legal requirements for a particular rule proposed by the agency conceded to have subject-matter jurisdiction.

11. Exec. Order 12,146, $\$ \S 1-401$ to $-402,44$ Fed. Reg. 42,657 (1979), makes a provision for resolution of "Interagency Legal Disputes," but does not define "legal disputes" beyond a specific inclusion of "question[s] of which [agency] has jurisdiction to administer a particular program or to regulate a particular activity." Id. $\$ 1-401$. The Justice Department, however, will not arbitrate nonlegal conflicts. Interview with Leon Ulman, supra note 1 . See also note 14 infra (limits on advice-giving function).

12. The Attorney General renders advice on "questions of law" for the President, 28 U.S.C. $\$ 511$ (1976), and for other members of the executive branch, 28 U.S.C. $\$ 512$ (1976). Exec. Order 12,146, 44 Fed. Reg. 42,657 (1979), directs executive-branch officials to adjourn otherwise irresolvable disputes to the Attorney General.

13. Preparation of the Attorney General's opinions and other advisory statements for the executive branch is a function of the Office of Legal Counsel (OLC). 28 C.F.R. $\$ 0.25$ (1979); see Ulman, Foreword to 1 Opinions of tife OfFice of Legal Counsel of the United States DEpartarent of JUSTICE, supra note 1 , at $v$ (summarizing history of OLC and its predecessors). Not all inter-agency legal disputes, hovever, are adjourned to OLC, and apparently some conflicts are settled by other clivisions of the Justice Department. See notes 16 \& 19 infra (resolution of inter-agency conflicts in course of litigation with external parties).

14. The status of these disputes as "questions of law" is self-evident from judicial decisions reviewing OLC determinations on their merits, see, e.g., Pueblo of Taos v. Andrus, 475 F. Supp. 359 (D.D.C. 1979), and appears essential to OLC's function as legal adviser to the executive branch, Interview with Leon Ulman, supra note 1; see Memorandum Opinion for the General Counsel, Department of Defense: Status of Baggers as Federal Employees-Fair Labor Standards Act, 1 Opinions of THE OfFice of Legal CounseL. of The United States Department of Justice, supra nòte 1, at 102, 107 (deeming "mixed question of law and fact ... beyond the authority of this Office"); see notes 11 \& 12 supra (definition of Justice Department's advice-rendering duties). 
partment's solution to their conflict, ${ }^{15}$ and the Department represents the executive branch in any subsequent judicial challenge from private parties. ${ }^{16}$

The legal dispute thus proceeds through two stages. First, the issues are argued and resolved within the executive branch. ${ }^{17}$ In the second stage-a stage that is routinely reached today ${ }^{18}$-the issues are re-examined in judicial review proceedings commenced by a private party. Within that two-step model, the Justice Department first serves as arbiter for the executive-branch disputants, and then acts as counsel for the United States. ${ }^{19}$

15. See Statement of Donald Elisburg, Assistant Secretary of Labor, quoted in Legal Times of Washington, Jan. 14, 1980, at 5, col. I (concerning role of Justice Department in resolving a dispute between Labor and Equal Employment Opportunity Commission: "We feel the Attorney General is the government's chief lawyer and we are obligated to abide by Justice's opinion."); Interview with Robert E. Litan, former member of Council of Economic Advisers staff, in Washington, D.C. (Dec. 17, 1979) (notes on file with Yale Law Journal) (when external party sues agency, even federal authorities that have disagreed with respondent tend to "close the wagon circle" around official opinion). Though not all of OLC's advice is intended to be binding, OLC expects agencies that seek final resolution of disputes from the Office to regard its opinions as binding. Interview with Leon Ulman, supra note 1.

16. The Judicial Code, 28 U.S.C. $\$ 516$ (1976), concentrates general authority for litigation, "[e]xcept as otherwise provided by law," in the Justice Department.

The ability to control litigation can fuse with the power to resolve intra-branch disputes. In California v. Kleppe, 604 F.2d 1187 (9th Cir. 1979), the Justice Department's defense of the EPA's claim of jurisdiction to regulate atmospheric conditions over the outer continental shelf amounted to a decision against an opposing claim by the Interior Department to regulate emissions in the same airspace. Interior could play no part in the litigation adverse to EPA's position. As one Interior Department official remarked, "Justice was representing EPA, so all we could do was sit on the sidelines and hope that EPA lost." Interview with staff member, Interior Department, in Washington, D.C. (December 17, 1979) (notes on file with Yale Law Journal).

17. OLC's solutions to inter-agency legal disputes are based on the merits of the controversy, and do not involve considerations of political expediency, in which OLC has no expertise. Interview with Leon Ulman, supra note 1.

18. Of the five major recent inter-agency legal disputes discussed here, two have already grown into litigation with external challengers. See note 7 supra (EPA-Interior conflict on air-emission regulation); note 6 supra (Agriculture-Interior conflict on management of western tract). One has reached the stage of internal settlement too recently to allow certain prediction of litigation, see note 8 supra (Interior-Commerce dispute concerning oil exploration controls), and another appears not yet to have been resolved within the executive branch, see note 25 infra (conflict on anti-discrimination requirements of public-sector contractors). The dispute between the Postal Service and the Internal Revenue Service, see note 82 infra, was deemed non-justiciable by OLC, which has proceeded to consider the merits of the controversy. Interview with Leon UIman, supra note $\mathrm{I}$.

19. The Justice Department's counsel status can involve noteworthy powers to alter the methods of arbitration within the executive branch. See Letter from Sanford Sagalkin, Acting Assistant Attorney General, Land and Natural Resources Division, to John E. Menario, Interior Department (July 13, 1979) (copy on file with Yale Law Journal); Letter from Sanford Sagalkin to John Goldstein, Director, Endangered Species Committee, Interior Department (July 17, 1979) (copy on file with Yale Law Journal) (discussing resolution of inter-agency dispute by Justice Department litigation counsel). 
The change in the adversarial structure of an inter-agency jurisdictional dispute as it moves from the first to the second stage of its development does not alter the identity of the issues involved. Both the court and the executive-branch arbiter must decide whether the agencies have received from Congress the powers and duties they claim. ${ }^{20}$ Moreover, problems of statutory interpretation usually arise only after one agency begins to act in response to a particular problem. ${ }^{21}$ Intra-branch disputes thus often reach the courts without substantial change in their factual setting. ${ }^{22}$

\section{The Problem of Delay and Uncertainty}

The traditional two-step process for clarifying regulatory powers and duties causes serious delays in the administrative process. Agency heads jealously guard their regulatory domains and may feel compelled to struggle in a variety of executive-branch forums with other authorities having conflicting interests. ${ }^{23}$ Even when all parties agree on the need for expedition, disputes can take years to reach the Justice Department for settlement. ${ }^{24}$ Justice Department resolution of an inter-agency conflict can itself take as long as one year. ${ }^{25}$ Those time

20. The attack on an agency's regulatory jurisdiction in court is likely to be joined with challenges to the agency action based on other grounds. See note 31 infra (comparative importance of proper jurisdictional basis for agency action and consequences of judicial finding of no jurisdiction to regulate).

21. Executive-branch agencies do not dispute ambiguities in regulatory statutes for purposes of abstract argument, and the Justice Department is reluctant to arbitrate disputes unless the contending agencies request it and can show that an authoritative decision is essential. Interview with Robert E. Litan, supra note 15.

22. New developments in a controversy's factual setting may occur between the time the dispute first arises among executive-branch authorities and the time when, if the twostep resolution process ran its course, the matter would reach the courts. See pp. 161619 infra (considerations of ripeness affecting inter-agency litigation).

23. The Interior Department-Commerce Department Coastal Zone dispute, see note 8 supra, for example, was carried to the Office of Management and Budget prior to adjournment to OLC. Interview with Teresa Hooks, former staff attorney, Office of the Solicitor, United States Department of the Interior, in Washington, D.C. (Oct. 3, 1979). No formal rules govern referrals of disputes to OLC from other sectors of the executive branch, apart from Exec. Order 12,146, \& 1-402, 44 Fed. Reg. 42,657 (1979), which directs that agencies that "are unable to resolve . . . a legal dispute" submit the matter to the Attorney General.

24. The Interior Department-Commerce Department dispute, see note 8 supra, took two years to reach OLC for arbitration. Interview with Teresa Hooks, supra note 23.

25. Interview with Leon Ulman, supra note 1. In at least one instance, a single decision from OLC has been inadequate to conclude a dispute. A disagreement over the legally per* missible scope of prohibitions on payment of employees' dues to discriminatory clubs by public-sector contractors based on Title VII of the Civil Rights Act of 1964 led to opinions from OLC in 1976 and again in 1977; the Civil Rights Division joined in the latter decision. It appears that the conflict, involving the Equal Employment Opportunity Commission and the Office of Federal Contract Compliance Programs in the Labor Department, remains unresolved despite Justice's efforts. See Legal Times of Washington, Jan. 14, 1980, at 5, col. 1 . 
lapses in turn precede the lengthy period that an external challenge to the final administrative action will consume; the court and the litigants must then duplicate the effort already invested by the executive branch in resolving the jurisdictional uncertainty.

If a reviewing court finds that the agency given clearance to regulate by the executive-branch arbiter did not possess statutory authority, ${ }^{26}$ the delay in implementation of Congress' plan will grow even longer. Whether or not the court reverses the internal resolution, the delay and duplication entailed in the entire process contribute to the time lag in the administrative process that the courts, ${ }^{27}$ commentators, ${ }^{28}$ and administrators ${ }^{20}$ themselves generally deplore.

Administrators confronted by unclear congressional guidelines may attempt to reduce the costs of internal disputes by deciding quietly among themselves at the beginning of a conflict which "lead" agency will assume the power to act. ${ }^{30}$ Such a stratagem will be partially

26. In interpretation of the statutory limits on agencies' powers, there exists no effective rule of judicial deference to the executive branch's solution to the controversy. See, e.g., Perkins v. Elg, 307 U.S. 325, 348-49 (1939) (rejecting formal opinion of Attorney Gencral); California v. Kleppe, 604 F.2d 1187, 1199 (9th Cir. 1979) (rejecting Justice Department view of jurisdictional dispute between EPA and Interior Department); Pueblo of Taos v. Andrus, 475 F. Supp. 359, 367 (D.D.C. 1979) (rejecting Justice Department solution to intra-branch conflict over jurisdiction to manage western lands).

27. See, e.g., FPC v. Hunt, 376 U.S. 515, 527 (1964) (chiding Commission for "nigh interminable" delay in licensing procedures); Nader v. FCC, 520 F.2d 182, 206 (D.C. Cir. 1975) (although "issues are complicated," court will enforce Commission's duty to decide them within reasonable time); National Petroleum Refiners Ass'n v. FTC, 482 F.2d 672, 690 (D.C. Cir. 1973) (noting that problems of "delay and inefficiency" at Commission survive both pro- and anti-activist reforms); cf. Environmental Defense Fund, Inc. v. Hardin, 428 F.2d 1093, $1094-1100$ (D.C. Cir. 1970) (where administrative inaction has same effect as denial of relief, courts will intervene as if action had been taken).

28. See Freedman, Review Boards in the Administrative Process, 117 U. PA. L. REv. 546,546 (1969) (noting criticism of administrative delays); $c f$. SubCommitTEE oN AdmINIstrative Practice and Procedure, Committee on the Judiciary, 86th Cong., 2d Sess., Report on Regulatory Agencies to the President-Elect (Comm. Print 1960) ("Inordinate delay characterizes the disposition of adjudicatory proceedings before substantially all of our regulatory agencies.")

29. See, e.g., In re American Tel. \& Tel. Co., 38 F.C.C.2d 213, 273 (1972) (Johnson, Comm'r, dissenting) (terming decade of delay in decisions on tariff applications "nothing short of amazing").

30. An example is the collaboration of the Interior and Energy Departments in promulgation of regulations to govern the rate of exploration and development of offshore oil under the Outer Continental Shelf Lands Act, 43 U.S.C. $\$ \$ 1331-1356$ (1976 \& Supp. II 1978) (OCSLA). Administrators at Energy and Interior believed that the Department of Energy Act of 1977, 42 U.S.C. \$ 7152(b)(3) (Supp. II 1978), might have required Energy to promulgate rules on exploration and development timetables for private oil enterprises, but the relation of the Energy Act to OCSLA's provisions for regulation by Interior was unclear. See 43 U.S.C. $\$ 1337$ (d) (Supp. II 1978) (Interior to ensuxe "prompt and efficient" exploration). After conferences between the two departments, the Energy Department elected not to act, and the Interior Department rewrote existing regulations under its OCSLA authority in lieu of any rulemaking by the Energy Department. Interview with Teresa Hooks, former staff attorney, Office of the Solicitor, United 
frustrated, however, if an external challenger persuades a reviewing court that the administrators erred in their choice of a "lead" agency. The risks of such errors seem particularly daunting since a decision against the "lead" agency would completely abrogate its rulings. ${ }^{31}$ Although much of the record built in the "lead" agency's attempts to make rules might be useful to another agency, ${ }^{32}$ current rulemaking practices would make a significant time saving in the second agency's rule promulgation unlikely. ${ }^{33}$ Thus, even if agencies choose to cooperate, uncertainties about regulatory jurisdiction involve irreducible risks of delay. ${ }^{34}$

\section{The Litigation Alternative}

Within the current system, the delays and uncertainties that often result from pursuit of executive branch unanimity are largely beyond

States Department of the Interior, in Washington, D.C. (Feb. 5, 1980). Officials at the Interior Department are unable to predict whether private parties will challenge the inter-agency decision to allot jurisdiction to Interior. $I d$.

31. Reversal on fundamental jurisdictional grounds leares little room for implementation of judicial policies favoring selective reversal of administrative actions. For a recent example of selective reversal, see Alabama Power Co. v. Costle, 606 F.2d 1068, 1093 (D.C. Cir. 1979) (preliminary opinion per curiam) (upholding portions of massive EPA regulation of stationary-source emissions, court rejected other portions of Agency regulations, based upon Agency interpretation of Clean Air Act Amendments "contrary to discernible legislative intent").

32. See Mobil Oil Corp. v. Federal Power Comm'n, 483 F.2d 1238, 1263 (D.C. Cir. 1973) (noting opportunity of Commission to use "evidence incorporated by reference from other proceedings" in reviewable rulemaking).

33. Notwithstanding continuous debate about appropriate procedural requirements for different agency functions, compliance with even the minimum procedural expectations for typical notice-and-comment rulemaking requires agencies to give interested parties a reasonable opportunity to participate in the administrative deliberations. See Mobil Oil Corp. v. Federal Power Comm'n, 483 F.2d 1238, 1263 n.93 (D.C. Cir. 1973) (though Commission might use evidence from other proceedings, adequate new opportunity for notice of and comment upon the evidence must be preserved); S. BREYER \& R. STEWART, ADMinistrative Law AND Regulatory Pouicy 478-81 (1979) (requirements of Administrative Procedure Act); J. Mashaw \& R. Merrill, Introduction to the American Public Liw System: Cases ANd MATERIals 322-23 (1975) (provisions in "model" rulemaking structure of Consumer Product Safety Act). Whether an agency could "apply" participation by private parties in a prior abortive proceeding before another agency to its own deliberations, perhaps by incorporation of the "record" in the prior proceeding, is unclear, and in respect to some agency functions, unlikely without cooperation of the private parties. Cf. 42 U.S.C. $\$ 7607(d)(7)(B)$ (Supp. II 1978) (Clean Air Act Amendments requiring EPA to reconsider a rule if party raises objection of "central relevance," if circumstances had made it impractical for party to raise the objection earlier).

34. Assuming that the administrators have agreed not to fight among themselves, the current approach to jurisdictional uncertainties can be mischievous in a more subtle way. Private parties could pressure the "lead" agency to favor their interests by agreeing not to sue the agency on jurisdictional grounds. The agency head would then face the possibility of a sweeping denial of the lawfulness of his rule, combined with frustration of his jurisdictional compromise with the agency that deferred to his own, unless he was prepared to satisfy the interests of the potential external challenger. 
the control of the administrators. Disputes that turn upon confusing statutory language could be resolved more effectively if inter-agency litigation were available to the officers with primary responsibility for execution of the legislative design.

\section{A. The Nature of the Action}

A serious uncertainty about statutory powers and duties that leads to an intra-branch dispute amounts-adopting a private-law metaphor -to a cloud upon the affected agencies' title to regulate. When such a conflict arises, an agency head should be permitted to commence a public law version of an action to quiet title: ${ }^{35}$ he would sue his executive-branch rival to clear his agency's authority to regulate the disputed subject-matter. ${ }^{36}$ This capacity to seek a declaratory judgment $^{37}$ would preserve the relationship between the Justice Department and the agencies. The Justice Department would retain its duties of representation in traditional external challenges to executive actions, and it would continue to arbitrate legal issues that agencies choose not to litigate.

When an administrator decides to litigate rather than to seek internal resolution of a jurisdictional contest, the nature of the outcome would not change: either resolution would determine the power of one agency, as against its executive-branch rivals, to undertake the disputed activity. The fundamental difference would be that the inter-agency suit would yield an answer that the courts would not need to re-examine after an agency had taken final action, such as promul-

35. Because a jurisdictional controversy affects the capacity of any claimant to regulate, an agency head sued for actual or threatened encroachment upon the plaintiff administrator's jurisdiction is likely to respond by counterclaim for declaratory relief against the plaintiff.

36. The administrator's action would be limited to the jurisdictional issue, and would not encompass all questions about the lawfulness of final agency actions that could arise in external parties' later challenges. See p. 1606 infra (effect of court's decision on jurisdictional dispute on scope of later judicial review proceedings). The pleadings in the action would present the agencies' difference on the matter of statutory construction that gave rise to the dispute, the pertinent allegations that the plaintiff's efforts to fulfill statutory duties were frustrated by the conflict, and a prayer for declaratory relief on the jurisdictional question.

37. It is unclear whether federal jurisdiction to hear an administrator's complaint could, apart from questions about its Article III justiciability, see pp. 1608-22 infra, rest upon existing jurisdictional statutes. Assuming, however, that current provisions for federal jurisdiction were inadequate, Congress could cure the statutory defect by legislation. Even if amendments to the jurisdictional statutes were not essential to confer jurisdiction on the courts, Congress might wish to address basic procedural questions through legislation. Congress might, for example, determine by statute which officials within the agencies should be deemed proper to commence the litigation. 
gating a rule. ${ }^{38}$ In practice, an administrator's complaint presenting the jurisdictional issue could come long before the controversy would reach the courts by way of the traditional two-step process. ${ }^{39}$

\section{B. Systemic Advantages of Litigation}

The question of whether to litigate or to use other settlement mechanisms should rest in each case with the dispute's principals. Assuming federal courts would subject each complaint to traditional jurisdictional requirements, ${ }^{40}$ the public interest in maintaining efficient systems for resolving inter-agency disputes will not be jeopardized by permitting administrators to decide whether to litigate. ${ }^{41}$ The practical advantages of inter-agency litigation are presented here in order to outline the general role litigation could play in an administrator's dispute settlement strategy.

\section{Avoidance of Uncertainty and Delay'}

Uncertainty about regulatory jurisdiction imposes hardships on the agencies, ${ }^{42}$ and authoritative judgments fixing the scope of adminis-

38. Full participation in the administrator's action by private parties interested in the dispute is essential if inter-agency litigation is to meet the goals of efficiency and procedural regularity. Liberal intervention rules for external parties, combined with appropriate issue-preclusive effects attached to the inter-agency lawsuit, would bring nonfederal parties into the litigation and ensure that the decision would be authoritative. Prudent application of issue-preclusion rules would not, however, prevent flexible judicial response to new jurisdictional disputes that could not be foreclosed in the first action. $C f$. National Automatic Laundry \& Cleaning Council v. Shultz, 443 F.2d 689, 703-04 (D.C. Cir. 1971) (reasonable res judicata effects can coexist with courts' need to restrict rulings on regulatory jurisdiction to broad questions without reaching separate questions of particular application that may arise later).

39. Nothing in the proposed form of inter-agency litigation developed by this Note, nor in the jurisdictional considerations it addresses, see pp. 1608-22 infra, would make it impossible for an administrator to seek a final judicial answer to an intra-branch dispute after the Justice Department had decided the issue in favor of his agency's rivals. But since the principal advantages of inter-agency litigation derive from early resolution of the conflict, before the Justice Department would have acted, most inter-agency lawsuits would seek court action prior to, and in lieu of, Justice Department arbitration.

40. See pp. 1608-22 infra.

41. The view of the public interest offered by the principals to an inter-agency dispute might be skewed by the agencies' special concerns. The court should consider such distortions in ruling on motions to dismiss or to stay proceedings. If the Justice Department were allowed to appear in the matter, another view of the public interest, perhaps reflecting that of the President, could be considered by the court. It must be assumed, however, that the judgment of the principals about their agencies' need for adjudication is entitled to great deference in entertaining such motions.

42. The hardships imposed on agencies by uncertainties and delays are assessed in Vining, Direct Judicial Review and the Doctrine of Ripeness in Administrative Law, 69 MrCh. L. REv. 1445, 1508-10 (1971). 
trative powers would spare the protagonists wasting their energies. ${ }^{43}$ Courts have long recognized that anticipatory actions determining the lawfulness of administrative activities assist not only the private complainants but the regulators as well. ${ }^{44}$ In fact, the public interest in early resolution of an inter-agency jurisdictional conflict is even higher than in external challenges to one agency's attempt to assert regulatory power. The external challenger's review proceeding assists a defendant agency by clarifying limits on its jurisdiction. ${ }^{45}$ The declaratory judgment on an inter-agency claim could do more, because it would free agencies found to have no statutory duties from any need to act further. ${ }^{46}$ With a decisiveness unique to the judicial process, ${ }^{47}$ the decree would concentrate both authority and responsibility in the hands of the proper officials.

By eliminating statutory ambiguities early in the regulatory process, inter-agency litigation possesses dramatic advantages over traditional, two-step resolution practices. A judicial decision on a fundamental jurisdictional question would not be deferred until an external party challenges the rulemaking activity of the agency that "won" the in-

43. Federal courts have traditionally favored anticipatory actions that will settle public rights and duties. See Vining, supra note 42, at 1446-91 (growth of remedies associated with Administrative Procedure Act). The classic introductory account of the utility of declaratory judgments, stressing private-law origins, is E. Borchard, Declaratory JudgMENTS 3-25 (2d ed. 1941).

44. See, e.g., National Automatic Laundry \& Cleaning Council v. Shultz, 443 F.2d 689, 702 (D.C. Cir. 1971) (“[P]rompt judicial review will benefit the total administrative process by resolving uncertainties . . . "); Cutler v. Kennedy, 475 F. Supp. 838, 851 (D.D.C. 1979) (continuing uncertainty about agency's statutory duties would mean "both plaintiffs and the federal defendant would suffer a hardship"); cf. S. BREYer \& R. STEwarT, supra note 33, at 521 (agency uncertainty about statutory procedural requirements may lead to "claborate panoply of formal procedures that will cripple the administrative process").

45. See note 44 supra (cases recognizing agency need for end to uncertainty about regulatory duties).

46. Like decisions in conventional anticipatory actions challenging prospective regulations, the judgment would also assist the private sector by disclosing, at an early point, the statutory and bureaucratic structures to which the courts would hold regulated enterprises responsible. By depriving private parties of the exclusive right to commence an action for declaratory judgment, the inter-agency litigation option would, however, confer the benefits of certainty on the private sector without permitting external parties to bargain their special standing for better treatment by the agencies. See note 34 supra (mischief where regulated parties exploit uncertainties and agency fear of suit). An administrator who could enter court to seek clarification of his powers, as against those of a rival agency, could not be coerced by threats of an identical jurisdictional challenge from a private party, because he could sue before a substantial commitment of regulatory resources would heighten his interest in avoiding external jurisdictional attacks.

47. Even more "decisive" than a judicial decree would be congressional action clarifying the jurisdictional question; but presumably Congress will not respond as readily to a problem of statutory interpretation as would the courts, who have traditionally assumed primary responsibility for statutory construction. See pp. 1621-22 infra (discussing relevance of possible congressional action to exercise of federal-court jurisdiction). 
ternal arbitration. At present, without an inter-agency litigation option, the time lag between initial identification of the conflict within the executive branch and final court action will depend upon the duration of the internal arbitration, and upon the time needed to complete some "final" administrative action that could be subjected to traditional judicial review. ${ }^{48}$

Because an administrator's action to secure his regulatory title would precede the main regulatory effort, an inter-agency suit could not dispose of all possible attacks on agency activities, and therefore could not accelerate resolution of all final review proceedings. ${ }^{49}$ Anticipation of jurisdictional attacks would, however, assist the courts and the parties to later proceedings by permitting them to focus on specific actions taken once jurisdiction has been established. ${ }^{50}$ The prior decision on jurisdiction would eliminate the possibility of reversal of the entire regulatory undertaking. Moreover, an early decision on the scope of an agency's powers in one case might guide the agency in later efforts to resolve jurisdictional uncertainties in other matters, and perhaps make resort to formal judicial or executive mechanisms unnecessary.

\section{Procedural Regularity}

Although the principal advantage of inter-agency litigation lies in avoidance of uncertainty and delay, federal court adjudication of an intra-branch dispute would also encourage procedural regularities that current practices do not guarantee. Some private parties who have an interest in the outcome of a jurisdictional dispute can participate in an intra-branch arbitration. ${ }^{51}$ Litigation, however, would

48. Even if the courts manipulated the requirement of "final" action in order to permit earlier review of a jurisdictional dispute upon a private party's application, the internal arbitration process would still require time. See p. 1600 supra (time consumed in pre-arbitration maneuvers and in OLC deliberations).

49. Even if Congress sought to curtail judicial review, it could not preclude consideration of the lawfulness of agency action taken against parties alleging violations of constitutional rights. Crowell v. Benson, 285 U.S. 22, 49.50 (1932); cf. Brown \& Williamson Tobacco Corp. v. Engman, 527 F.2d 1115, 1119 (2d Cir. 1975), cert. denied, 426 U.S. 911 (1976) (noting "due process right to contest the validity of a legislative or administrative order" (emphasis in originaI)). See also S. BREXER \& R. STEWART, supra note 33, at 916-21 (constitutional limits on preclusion of judicial review).

50. Thus, the courts might remand the matter for perfection of the administrative "record," see, e.g., International Harvester Co. v. Ruckelshaus, 478 F.2d 615, 649-50 (D.C. Cir. 1973), for a fuller statement of the agency's rationale, see, e.g., National Nutritional Foods Ass'n v. Weinberger, 512 F.2d 688, 703 (2d Cir.), cert. denied, 423 U.S. 827 (1975), or because, despite a statutory mandate to regulate, the particular action taken was meritless, see, e.g., Aqua Slide 'N' Dive Corp. v. Consumer Product Safety Comm'n, 569 F.2d 831, 843-44 (5th Cir. 1978).

51. Interview with Teresa Hooks, supra note 23; Interview with Leon Ulman, supra note 1 . 
enhance participatory fairness in two ways. Parties that lack the contacts and resources needed for continual monitoring of the executive branch could more easily obtain notice of an inter-agency action in time to influence the outcome, perhaps by intervention. ${ }^{52}$ In addition, all external parties' participation would be limited and disciplined by the formalities of reasoned argument to a court, a procedural advantage of judicial proceedings that rules on ex parte contacts in executive-branch deliberations can only approximate. ${ }^{53}$

Litigation would also benefit the terms on which the members of the executive branch participate in settlement of a dispute. Inter-agency lawsuits would release the Justice Department from an arbitrative function that, in situations grave enough to require resolution by some superior or external authority, could generate tensions between Justice and coordinate departments affecting cooperative regulatory efforts. $^{54}$ If agencies involved in legal conflicts knew they could litigate particularly serious legal issues, the solution of other, non-legal disputes might benefit: judicial resolution of legal conflicts would leave administrators free to solve policy problems solely on their merits. In addition, litigation would dispel the appearance of intrabranch unanimity that can conceal from public view serious confusions in Congress' regulatory programs. ${ }^{55}$ At the same time, litigation prior to Justice Department arbitration would spare both the

52. Settlement of an inter-agency jurisdictional conflict in court would tend partially to equalize the relative abilities of external parties to influence resolution of the dispute. Because a court must decide the issues on the basis of representations in court after filing of the complaint-the publicity-creating event-the advantage obtained by early warnings of a nascent legal conflict to powerful regulated interests from sources in the agencies will be subdued: any head start that experienced or well-provisioned private groups would have obtained from early participation in the executive-branch discussions will play only an indirect part in the argument in court. Cf. Stewart, The Reformation of American Administrative Law, 88 HARv. L. REv. 1667, 1713-15 (1975) (privileged access of regulated parties to information about agency activities noted as basic element of representational imbalance).

53. The importance to "the ideal of reasoned decisionmaking" of avoiding ex parte contacts by parties unduly seeking to influence official actions is well-settled. Home Box Office, Inc. v. FCC, 567 F.2d 9, 56-57 (D.C. Cir.), cert. denied, 434 U.S. 829 (1977) (noting that disfavor of ex parte contacts not restricted to judicial or quasi-judicial settings). See also Note, Due Process and Ex Parte Contacts in Informal Rulemaking, 89 YaLE L.J. 194 (1979) (due-process basis for ex parte prohibitions and controls). Inter-agency litigation would transfer the decisionmaking process from the less-ordered executive-branch setting that current ex parte rules attempt to control to the federal courts.

54. The Justice Department prefers to avoid intervention in inter-agency disputes. Interview with Robert E. Litan, supra note 15.

55. Cf. Mashaw, Civil Liability of Government Officers: Property Rights and Official Accountability, 42 LAw \& Contemp. ProB. 8, 33 (1978) (litigation against public officers useful in generating and distributing information about externalities of government activities). 
courts and the executive branch from the risk of institutionally embarrassing variances in interpretation of the statutes. ${ }^{56}$

\section{Jurisdictional Considerations}

If the administrators in a legal dispute elect to pursue litigation, the federal court to which they turn must first resolve a critical threshold issue: is an intra-branch legal dispute justiciable? ${ }^{57}$ Constitutional and prudential limits on judicial competence must control even an administratively sound decision to carry an inter-agency conflict into court. ${ }^{58}$

The innovative characteristics of intra-branch lawsuits should shape the inquiry into justiciability. Inter-agency claims involve unconventional party structures and timing, and the litigation occurs in an unusual institutional setting. None of those distinctive features would, however, violate current norms of justiciability associated with Article III. ${ }^{59}$

56. Federal courts are sensitive to the risk that variant positions on legal questions will raise a problem of separation of powers within the national government. See Baker v. Carr, 369 U.S. 186, 217 (1962) (courts to avoid "the potentiality of embarrassment from multifarious pronouncements by various departments on one question"); pp. 1620-21 infra (political question).

57. It has been suggested that, should Article III prohibit inter-agency litigation, different tribunals not restricted to Article III standards for jurisdiction might hear intrabranch legal disputes. Note, Judicial Resolution of Administrative Disputes Between Federal Agencies, 62 HARv. L. REv. 1050, 1056 (1949) (proposing vesting of jurisdiction in District of Columbia courts). But even if suitable courts not bound to Article III could be identified, any review of their decisions in an enforcement action would have to occur in an Article III court. See note 49 supra (requirement of judicial review by Article III tribunal). Thus, the delays and uncertainties that afflict the current method of intrabranch dispute resolution, see p. 1600 supra, would persist; the matter could not be settled until the Article III court had decided the issues.

58. Cf. United States v. Nixon, 418 U.S. 683, 692-93 (1974) (conflict, deemed "intrabranch dispute" by President's counsel, justiciable if court competent to decide the issues and grant order).

59. U.S. Consr. art. III, $\S 2$ ("The judicial Power shall extend to all Cases, in Law and Equity, arising under this Constitution, the Laws of the United States, and Treaties made, or which shall be made, under their Authority. . . .")

In formulating the requirements of justiciability, some courts have seen a difference between the "constitutional" and "prudential" elements of the doctrine. According to the distinction, Congress could cure through legislation what might otherwise be a "prudential" defect in a case's justiciability, but it could not render a controversy failing to meet Article III requirements justiciable. See Warth v. Seldin, 422 U.S. 490, 498-501 (1975) (distinguishing "minimum constitutional mandate" from "matters of judicial selfgovernance"); Associated Indus., Inc. v. Ickes, 134 F.2d 694, 704 (2d Cir.), vacated on suggestion of mootness, 320 U.S. 707 (1943) (Congress may authorize suits by "private Attorney Generals" if "actual controversy" exists). This Note considers both "prudential" and "constitutional" norms together to demonstrate the permissibility of interagency suits in both of the Warth dimensions, and so the often subtle specific classifica. tion of particular requirements as "prudential" or "constitutional" does not affect its 


\section{A. Party Structure}

The party structure of an inter-agency suit would differ from other forms of government litigation in that the plaintiff agency would sue for itself, without clearance or assistance from the Justice Department. The first question is thus whether such a plaintiff has standing to sue. The status of both litigants as members of the executive branch presents a second issue of justiciability, sometimes considered a requirement of "adverse parties."

\section{Standing}

All civil plaintiffs face two standing doctrine requirements in public actions. A plaintiff must demonstrate sufficient interest-often called "personal stake" 00 -in the outcome of the suit to ensure that he will assert his claims with the thoroughness and responsibility essential to the adversary nature of an Article III "case." 61 The plaintiff must also allege some actual or threatened "harm" or "injury" that renders judicial action appropriate. ${ }^{62}$ Limits on the type of harm or in-

conclusion that such lawsuits would violate neither set of norms. Enactment of new jurisdictional provisions by Congress to structure inter-agency suits might, however, be advisable in establishing procedures for the litigation. See note 37 supra (suggesting legislation to designate agency officials entitled to commence suit on agency's behalf).

60. See, e.g., Duke Power Co. v. Carolina Environmental Study Group, Inc., 438 U.S. 59,72 (1978) (plaintiff must "have 'alleged such a personal stake in the outcome of the controversy as to assure that concrete adverseness which sharpens the presentation of issues upon which the court so largely depends ...." ") (quoting Baker v. Carr, 396 U.S. 186, 204 (1962)).

61. The function of the "interest" test for standing is thus to test the litigative capabilities of the complainant. Association of Data Processing Serv. Organizations, Inc. v. Camp, 397 U.S. 150, 172-73 (Brennan, J.) (1970) (parties must "frame the relevant questions with specificity, contest the issues with the necessary adverseness, and pursue the litigation vigorously"). The interest test's function is highlighted by cases in which plaintiffs have been allowed to raise claims vindicating legal rights of other parties that the plaintiffs themselves do not possess. If the plaintiff's own stake ensures adequate representation of the claims others might have, he may represent those claims as a surrogate. Association of Data Processing Serv. Organizations, Inc. v. Camp, 397 U.S. 150, 153-54 (1966); FCC v. Sanders Bros. Radio Station, 309 U.S. 470, 477 (1940); Pierce v. Society of Sisters, 268 U.S. 510, $518-19$ (1925); Air Reduction Co. v. Hickel, 420 F.2d 592, 594 (D.C. Cir. 1969); see Stewart, The Reformation of American Administrative Law, 88 HARv. L. Rev. 1667, 17301735 (1975) (analyzing surrogate standing doctrine); cf. Sosna v. Iowa, 419 U.S. 393, 398 . 400 (1975) (since representation adequate and issues otherwise impossible to litigate, class action should not be dismissed despite mootness of named plaintiff's claims).

62. Prevailing formulations of the "harm" requirement are sometimes sub-divided into three elements. A plaintiff must show (I) some actual or threatened injury, Warth v. Seldin, 422 U.S. 490, 499 (1975), also termed "injury in fact," Association of Data Processing Serv. Organizations, Inc. v. Camp, 397 U.S. 150, 151-54 (1970) (cited in Warth v. Seldin, 422 U.S. at 499); (2) that the injury resulted from the defendant's conduct, Linda R.S. v. Richard D., 410 U.S. 614, 618 (1973); and (3) that the injury is capable of redress by a favorable decision, Village of Arlington Heights v. Metropolitan Hous. Dev. Corp., 429 U.S. 252, 262 (1977). See Harrington v. Bush, 553 F.2d 190, 204-07 (D.C. Cir. 1977) (summarizing harm criteria applicable to all litigants). See also note 77 infra (discussing functions of harm criteria). 
jury the courts will recognize acknowledge that judicial remedies cannot correct any generalized public "wrong" a plaintiff might allege. ${ }^{03}$

The Agency's "Interest" in the Outcome. The interest of an executive-branch agency that sues another federal authority in a jurisdictional dispute stems from the asserted ${ }^{64}$ congressional commitment of regulatory power to the plaintiff agency. Federal courts have held that regulatory authorities have an institutional interest in performing statutory duties that is adequate to confer standing to challenge other governmental activities that are prejudicial to fulfillment of the statutory mandate. ${ }^{65}$ As early as 1939, the Supreme Court recognized the "legitimate interest" 66 of federal agencies in preserving the integrity of the statutes they administered, and concluded that such an interest gave the agencies a capacity to litigate their claims without Justice Department support. ${ }^{67}$

In light of the function of the "interest" test for standing, the

63. Warth v. Seldin, 422 U.S. 490,499 (1975). The limits of judicially cognizable harm were tested in United States v. Richardson, 418 U.S. 166, 176-80 (1974) (generalized grievances about government operations nonjusticiable), and Schlesinger v. Reservists Comm. to Stop the War, 418 U.S. 208, 220-23 (1974) (nonspecific claims of injury not susceptible to judicial solution).

64. Courts examining the justiciability of claims do not question the merits of plaintiffs' legal theories, Warth v. Seldin, 422 U.S. 490,501 (1975), nor gainsay the complaint's allegations of fact, id. at 501; accord, Nash v. Califano, 613 F.2d 10, 14 (2d Cir. 1980).

65. The leading lower court decision is Washington Util. \& Transp. Comm'n v. FCC, 513 F.2d 1142, 1146-53 (9th Cir.), cert. denied, 423 U.S. 836 (1975). There, the Washington state utilities commission alleged that an FCC decision impermissibly interfered with the state agency's performance of the regulatory duties assigned to it by the state legislature. The allegation that "the FCC order will affect the discharge . . . of its duty" was adequate to confer standing. 513 F.2d at 1149; see Starbuck v. City and County of San Francisco, 556 F.2d 450, 459 n.17 (9th Cir. 1977) (Washington Utilities rule could apply to municipalities that also have statutory public-police obligations); Pennsylvania v. Kleppe, 553 F.2d 668, 682 (D.C. Cir. 1976) (Lumbard, Sen. Cir. J., dissenting) (IFashington Utilities rule permits agency standing "to assure compliance with the congressional will ... by the administrative agency charged with its enforcement . . . " ) (quoting Washington Util. \& Transp. Comm'n v. FCC, 513 F.2d at 1153); cf. Nuesse v. Camp, 385 F.2d 694 (D.C. Cir. 1967) (interests of state banking authority, distinct from those of private challengers of decision by U.S. Comptroller of the Currency, permitted intervention).

66. Coleman v. Miller, 307 U.S. 433, 441-442 (1939) (dictum).

67. In Coleman v. Miller, 307 U.S. 433 (1939) the Court, in holding that state legislators had standing to seek review of a state-court decision on legislative procedure, observed, "[T] here has been recognition of the legitimate interest of public officials and administrative commissions, state and federal, to resist the endeavor to prevent the enforcement of statutes in relation to which they have official duties." 307 U.S. at $441-42$ (dictum) (emphasis added). See also Board of Educ. v. Allen, 392 U.S. 236, 241 n.5 (1968) (stace officials have standing to challenge determination by other state authorities that would prevent plaintiffs from performing official duties in accord with federal constitutional requirements). Both Coleman and Allen involved appeals from state-court judgments, but Article III jurisdictional requirements do not depend upon whether a case arises as an original federal action or by appeal from state jurisdictions. Doremus v. Board of Educ., 342 U.S. 429,434 (1952). 
position adumbrated by the Supreme Court in 1939, and subsequently adopted by the lower courts, ${ }^{68}$ is sound. Few institutional plaintiffs are likely to represent more thoroughly an issue of administrative jurisdiction than an agency actually claiming the power to act; indeed, the capacity of executive-branch agencies to litigate seems indistinguishable from that of the independent agencies that currently possess unchallenged standing to oppose other federal authorities. ${ }^{90}$ It follows from the courts' recognition of an institutional interest in effective regulation that the agencies have a cognizable interest in establishing clear regulatory title. A firm jurisdictional basis is indispensable to successful administration of a congressional regulatory program. ${ }^{70}$

The "Harm" the Remedy Would Address. Satisfaction of the "harm" criteria for standing, closely linked to the requirement of an "interest" in the suit's outcome, ${ }^{71}$ begins with a showing of "injury in

68. See note 65 supra (recent applications of agency standing analysis in Coleman v. Miller, 307 U.S. $433,441.42$ (1939)).

69. See note 4 supra (standing of independent agencies to sue). To support its general conclusion about agency standing, the Supreme Court in Coleman v. Miller noted instances in which the independent agencies had litigated without support of the Justice Department. Coleman v. Miller, 307 U.S. 433, 442 (1939).

The litigative capacities of the executive-branch agencies also seem indistinguishable, on a functional level, from those of state officers and agencies who in many jurisdictions are permitted to sue one another for declaratory judgments. See, e.g., Attorney General v. Department of Pub. Util., 342 Mass. 662, 665, 175 N.E.2d 255, 257 (1961). See also Develop. ments in the Law-Declaratory Judgments, 1941-1949, 62 HARv. L. REv. 787, 875-76 (1949) (collecting similar cases from various state jurisdictions).

70. Other participants in national government have recognized institutional interests in performance of constitutional and statutory functions adequate to confer standing in Article III courts. Both houses of Congress and its committees have standing to seek civil remedies in aid of their investigatory powers. United States v. American Tel. \& Tel. Co., 551 F.2d 384, 393 (D.C. Cir. 1976); Senate Select Comm. v. Nixon, 498 F.2d 725, 731 (D.C. Cir. 1974). Congressmen have standing to sue the President and other officials to prevent nullification of some exercises of their power to vote, Kennedy v. Sampson, 511 F.2d 430, 433 (D.C. Cir. 1974) (standing to challenge constitutionality of pocket veto), and arguably to vindicate their legislative right to be consulted on treaty termination, Goldwater v. Carter, 100 S. Ct. 533 (1979) (Court declined to find that congressional plaintiffs lacked standing).

States, territories, and municipalities have been permitted to protect their own regulatory interests by suing federal agencies that compromise their interests. See, e.g., Starbuck v. City of San Francisco, 556 F.2d 450, 459 (9th Cir. 1977) (although private interest in challenging inaction of United States Secretary of Interior did not exist, city itself might sue to enforce federal water control law against Secretary); City of Davis v. Coleman, 521 F.2d 661, 671 (9th Cir. 1975) (city may sue United States transportation Department where Department's activities adversely affect city's efforts to provide services pursuant to state law); Government of Guam v. Federal Maritime Comm'n, 329 F.2d 251, 252.53 (D.C. Cir. 1964), cert. denied, 385 U.S. 1002 (1967) (territory has interests in performance of regulatory duties distinct from parens patriae).

71. The requirement of judicially cognizable "harm" is sometimes presented as a restatement of the standing doctrine's requirement of a substantial interest in the outcome of the litigation. See, e.g., Duke Power Co. v. Carolina Environmental Study Group, Inc., 438 U.S. 59, 72 (1978). The connection is close because the opportunity for redress 
fact." 72 Courts have found "injury in fact" in the alleged impairment of agencies' recognized interest in effective, lawful regulation. ${ }^{3}$ Even individual members of an agency incur "injury" when other officials interfere with their fulfillment of statutory expectations. ${ }^{74}$

Insofar as an agency plaintiff must show that its alleged injury is also "traceable" to the defendant's conduct, ${ }^{75}$ the link is easily established: the complaint could allege that the defendant's own attempts to regulate placed a cloud upon the plaintiff's regulatory title. ${ }^{70}$ To the extent that the "harm" requirement attempts to ensure that the decree will provide an effective remedy, ${ }^{77}$ a complaint for declaratory

of some harm arguably creates an interest in obtaining a judicial remedy. Yet each requirement has a distinct functional emphasis, see pp. 1609-10 supra, and some decisions on standing are explicable only by distinguishing the two components. Compare Sierra Club v. Morton, 405 U.S. 727, 736 (1972) (undoubted desire to litigate environmental claim inadequate to confer standing on competent private organization that alleged no palpable harm to its members) with United States v. Students Challenging Regulatory Agency Procedures, 412 U.S. 669, 686-90 (1973) (allegation of "injury in fact" to association members cured standing defect found in Sierra $C l u b$ ). See also United States v. Richardson, 418 U.S. 166, 177 (1974) (genuine personal interest in outcome of suit inadequate to confer standing if "harm" alleged amounted to generalized, political grievance); Reuss v. Balles, 584 F.2d 461, 472 (D.C. Cir. 1978) (Wright, C.J., concurring) (plaintiff lacks standing when does not appear that decree sought would protect injured property rights).

72. See note 62 supra (requirement of actual or threatened injury, or "injury in fact"). Some courts have associated the "injury-in-fact" requirement with a rule that injury be done to an interest "arguably within the zone of interests to be protected or regulated by the statute or constitutional guarantee in question." Nash v. Califano, 613 F.2d 10, 14 (2d Cir. 1980) (quoting Association of Data Processing Serv. Organizations, Inc. v. Camp, 397 U.S. 150, $153(1970)$ ). If the "injury in fact" consists of impairment of statutory functions, then its location within the statutory "zone" is self-evident. See Nash v. Califano, 613 F.2d at 17.

73. See note 65 supra (citing cases on agencies' interest in performance of statutory duties).

74. In Nash v. Califano, 613 F.2d 10 (2d Cir. 1980), the court held that a federal administrative law judge had standing to challenge attempts by the Secretary of Health, Education, and Welfare to regulate the plaintiff's performance in ways that the plaintiff claimed would improperly influence administrative adjudication, in violation of the Administrative Procedure Act and the Fifth Amendment. Because "Nash and his colleagues allegedly receive mandatory, unlawful instructions regarding every detail of their judicial role," the court concluded that the plaintiff had shown the requisite "injury in fact." 613 F.2d at 16.

75. See note 62 supra (requirement of causal link).

76. A showing of "substantial likelihood" that injury would not occur without the defendant's conduct is all the "harm" test requires. Duke Power Co. v. Carolina Environmental Study Group, Inc., 438 U.S. 59, 75 (1978). See also Orr v. Orr, 99 S. Ct. 1102, 1108 (1979) (in Fourteenth Amendment equal protection claim, attenuation of causal link between allegedly underinclusive statute and plaintiff's harm does not render case hypothetical).

77. See note 62 supra (requirement that decree be efficacious). The requirement of a causal link betwen defendants' conduct and plaintiffs' harm can be subsumed within the expectation that a decree would remedy the harm. Unless the harm doctrine's requirement of a causal link between the injury and the defendant's conduct is meant to satisfy, at the threshold of the lawsuit, some normative expectation that the defendant be "guilty" of interfering with the plaintiff's interests-a proposition that is nowhere articulated in the 
relief would also satisfy that criterion of standing. The declaratory judgment the plaintiff seeks would dispel the cloud upon its regulatory title by stating, as a matter of statutory construction, that it possesses the power to act free of the defendant's interference. ${ }^{78}$

\section{2. "Adverse Parties"}

Among the earliest formulas associated with Article III analysis was a requirement that litigants be proper "adverse parties."79 Except as a restatement of the rule prohibiting collusive suits, ${ }^{80}$ the functional role of the "adverse parties" formula is elusive. A conceptually independent "adverse parties" formula has never been the basis for dismissal of a complaint for want of Article III jurisdiction. ${ }^{81}$ One concern about the "adverseness" of an inter-agency suit may depend upon the propriety of directing an order to an executive-branch agency when the President himself could have responded with a simi-

leading standing cases-then the causal-link requirement collapses into the harm criterion's third element: it helps ensure that an order directed at the defendant's conduct will strike at the source of the plaintiff's injury and remedy the harm. See Orr v. Orr, 99 S. Ct. $1102,1107.08$ (1979) (conflating causal-link and decree-efficacy tests in allowing standing); Linda R.S. v. Richard D., 410 U.S. 614, 617-619 (1973) (same approach taken in denying standing). Presumably the third element exists as an independent part of the "harm" inquiry because more than a causal link between defendant's conduct and plaintiff's injury is essential to an efficacious decree. Moreover, unless the "injury-in-fact" requirement simply restates the expectation of some concrete "interest" in the outcome of the litigation, see note 71 supra, then it, too, serves the same purpose as the third element of the "harm" criterion: an order cannot have any remedial effect if in fact no wrong was suffered.

78. Among recent judicial orders directed to federal agencies, even those that have required substantial systemic reform of administrative programs have not been deemed too ambitious if the plaintiffs' interests would be enhanced. Note, Judicial Control of Systemic Inadequacies in Federal Administrative Enforcement, 88 YALE L.J. 407 (1978) (reviewing decisions granting relief against large-scale lapses in enforcement of federal laws); see, e.g., White v. Mathews, 559 F.2d 852 (2d Cir. 1977), cert. denied, 435 U.S. 908 (1978) (detailed "enforcement injunctions" directed at federal agencies proven derelict in performance of statutory duties); Adams v. Richardson, 480 F.2d 1159 (D.C. Cir. 1973) (same). Judicial orders resolving inter-agency jurisdictional conflicts appear modest by comparison with those "enforcement injunctions."

79. South Spring Hill Gold Mining Co. v. Amador Medean Gold Mining Co., 145 U.S. 300,301 (1892).

80. Collusive suits involve corruption of the adversarial process when the nominal opponents in a suit cooperate to seek a particular outcome. See 13 C. WRIGHT, A. Miller, \& E. Cooper, Federal Practice and Procedure $\$ 3530$ (1975). The leading early expression of the rules against collusion in private actions is Lord v. Veazie, 49 U.S. (8 How.) 251, 255 (1850). See also United States v. Johnson, 319 U.S. 302, 305 (1943) (applying doctrine developed in common law proceedings to feigned suit challenging official action under statutory review procedures).

81. Thus in United States v. Nixon, 418 U.S. 683, 693 (1974), the Court met a suggestion from the President's counsel that a controversy was nonjusticiable if it involved "' $a$ 'jurisdictional' dispute within the Executive Branch" with the observation, "The mere assertion of a claim of an 'intra-branch dispute,' without more, has never operated to defeat federal jurisdiction; justiciability does not depend on such a surface inquiry." 
lar order. Such a problem ought, however, to be considered in its modern analytic setting as a question relating to the separation of powers doctrine, rather than as one stemming from the litigants' party structure. ${ }^{82}$

Collusion, the problem that a functionally legitimate "adverse parties" formula might address, is not inherent in the party structure of inter-agency litigation. ${ }^{83} \mathrm{~A}$ merely speculative possibility that collu-

82. See pp. 1619-22 infra (questions arising from specialized functions of President and the courts).

The absence of independent functional significance for the "adverse parties" category, except as a formula implicating collusion, is reflected in the argument in a recent memorandum by OLC on the justiciability of a legal issue concerning the Postal Service's tax liability to the Treasury. OLC confronted a dispute between the Postal Service and the Treasury Department concerning the Postal Service's tax liability for line-haul and handling charges it paid to private transporters. See OLC 77-22, supra note 1 . Without suggesting that adjudication of the dispute between the Postal Service and the Internal Revenue Service (IRS) involved a risk of collusion that could deprive the courts of jurisdiction, the memorandum concluded that Article III courts could not hear the dispute between the Postal Service and IRS in any form, apparently because both disputants were agencies of the national government. The memorandum conceded that the Postal Service, like the ICC in United States v. ICC, 337 U.S. 426 (1949), was an independent agency: OLC 77-22, supra note 1 , at 83 . The memorandum also noted, however, that in the ICC case private railroad companies interested in the suit's outcome were "active parties in the agency and judicial proceedings, vigorously defending their private interests." Id. at 83-84. No similar adrerse interests that a court could recognize seemed to OLC to be present in the IRS dispute: "[t]he interests represented by both the Postal Service and the IRS are facets of the public interest, not truly private interests adverse to those of the Federal Government as a whole." Id.

The memorandum's analysis seems inadequate. In the ICC case, the participation of the railroad intervenors was not critical to the suit. It would have been unsound for the court to have grounded its jurisdiction on the non-mandatory presence of private intervenors in the litigation; at the least, the court might have been expected to wait until the railroads commenced actions against the War Department to enforce the tariffs awarded to them by the ICC. The memorandum's analysis is similarly uninformed by recent derelopments on the justiciability of agency "interests" that conflict with other governmental activity. The memorandum nowhere explains what OLC deemed the "facets of the public interest" it attributed to the IRS and thc Postal Service, nor docs it define the "interests . . of the Federal Government as a whole." Id.; see pp. 1609-13 supra (standing doctrine). The integrity of OLC's argument thus depends upon a narrow reading, limited to the case's facts, that deprives it of doctrinal significance-i.e., that Postal Service tax liability is not litigable-or must depend upon a talismanic belief that having two disputants within the national government makes a conflict between them, lacking intervenors, non-justiciable because the conflict does not involve adverse interests or private parties. But see United States v. Nixon, 418 U.S. 683, 693 (1974) ("mere assertion" of intrabranch structure of lawsuit inadequate to defeat jurisdiction).

83. It is noteworthy that the federal courts have traditionally tolerated actions in which a risk of collusion existed; indeed, such a risk will always exist, given the incentives for obtaining authoritative judicial decisions to establish order in private relations or settle public rights. See Cheng Fan Kwok v. Immigration and Naturalization Serv., 392 U.S. 206 (1968) (with government aligning itself with petitioner in challenge to decision below, and Court appointed amicus curiae arguing to affirm, decision obtained on the merits of the claim). As in the party structure of Cheng Fan Kwok, where the risk of collusion, being express on the appeal, far exceeded that in the inter-agency suits proposed here, other parties to the intra-branch suit, for example, private intervenors, will help ensure adrersarial argument. See p. 1615 infra (role of external parties in intra-branch litigation). 
sion may occur cannot defeat jurisdiction: ${ }^{8 t}$ should a court later discern collusion in the conduct of the litigation, dismissal of the action would be appropriate. ${ }^{85}$ Because they have chosen to seek judicial resolution of their conflict, the adversaries in an inter-agency suit would be entitled to the presumption of the good-faith antagonism that makes any lawsuit workable. so $^{\text {so }}$

Any fear that the President himself would attempt to control the administrators' lawsuit reflects an incomplete view of such litigation and of the role of the court. ${ }^{87}$ Intervention by external parties would ensure that the argument of the jurisdictional dispute would remain vigorous and independent. ${ }^{88}$ The plenary power of the court to dismiss actions that appear to have been distorted by the Chief Executive beyond hope of correction would also frustrate an attempt at

84. Cf. United States v. Nixon, 418 U.S. 683, 696 (1974) (although "theoretically possible" for one party to assume control of litigation, case remains justiciable unless such event occurs).

85. See, e.g., United States v. Johnson, 319 U.S. 302 (1943) (judgment vacated on appeal upon showing of collusion).

86. Adverse publicity that would attend any dismissal of an inter-agency complaint for collusion would help deter administrators from non-adversarial conduct of their litigation. News of a suit's dismissal due to collusion would also draw congressional attention to the underlying jurisdictional conflict within the executive branch, if one truly existed, and thus speed resolution of the dispute by legislation resolving the agencies' interpretive conflict. See also note 89 infra (similar analysis of consequences of dismissal due to presidential interference).

87. An inter-agency suit has three stages at which the President might attempt to control it. The first involves the administrator's decision whether to commence the action; the second consists of the post-filing preparation of the case and all other phases of litigation prior to judgment; and the third is implementation of the court's final decision. Only the second phase involves matters that the classic doctrine of collusion addresses. Problems relating to the implementation phase are properly considered as issues of "finality." See pp. 1621-22 infra.

Many of the institutional deterrents that would impede presidential efforts to dominate the decision to litigate resemble the deterrents to collusion once a suit has begun. Just as external parties' participation in an intra-branch lawsuit would help preserve the integrity of the argument in court, so the influence and support of Congress, its committees, lobbying groups, the press, and state and local governments would complicate any significant assertion of presidential control over an administrator's strategy for settlement or litigation prior to the filing of a complaint. Cf. Note, supra note 2, at 562-63 (1980) (describing political forces shaping regulatory activities of the executive branch). At any stage, only by actually terminating a willfully independent administrator could the President decisively overcome the normal constraints on his power. Termination, however, would-like dismissal of a complaint in an action's second phase-draw public attention to the underlying jurisdictional dispute and invite congressional reaction. It is more likely that the President would favor the filing of an inter-agency complaint: the loss in the appearance of executive-branch unanimity-already violated if an intra-branch dispute is serious enough to draw public notice-would be outweighed by the image, and reality, of efficient resolution of inter-agency conflicts.

88. Cf. Pasadena City Bd. of Educ. v. Spangler, 427 U.S. 424, 431 (1976) (though original plaintiffs had lost interest in outcome of suit, presence of United States, as statutory intervenor pursuant to Civil Rights Act, 42 U.S.C. $\$ 2000 h-2$ (1976), forestalled mootness and permitted adjudication on merits). 
interposition, because it would make undue presidential involvement fruitless. ${ }^{80}$ The appropriate method of presidential involvement in the lawsuit is participation on his behalf by the Justice Department. ${ }^{90}$ In practice, it is more likely that the Chief Executive would welcome litigation rather than resist it: an inter-agency lawsuit would authoritatively resolve a conflict among his officers that was impeding administrative efficiency ${ }^{91}$ and that would probably reach the courts anyway. ${ }^{92}$

\section{B. The Timing of the Litigation}

One important innovation and advantage of inter-agency litigation lies in the opportunity it could provide for bringing the statutory dispute to court prior to the formulation of the internal, executivebranch position. That difference in timing would, however, require the courts to determine whether the questions involved in the dispute among the agencies are ripe for judicial resolution without attainment of intra-branch unanimity. The ripeness doctrine embodies both an Article III requirement for a "case" and other, prudential constraints on the exercise of federal judicial power. ${ }^{93}$

\section{The Article III Ripeness Requirement}

In its constitutional dimension, the ripeness requirement prevents a court from adjudicating a dispute whose issues are too vague for judicial analysis or resolution. ${ }^{9 \pm}$ Anticipatory actions that have failed

89. Dismissal of a complaint owing to the President's exertion of the powers of a dominus litus would undoubtedly draw public attention and stimulate congressional reaction, perhaps in the form of a resumption of interest in the problems the executivebranch disputants sought to regulate. If Congress were moved to clarify the uncertainty about its intention that accounted for the underlying intra-branch conflict, the court's action in dismissing the complaint would have accomplished the final goal of the interagency suit, resolution of the jurisdictional dispute.

90. See note 41 supra (briefing by Justice Department on President's behalf in interagency suit).

91. See pp. 1600.02, 1604-08 supra (costs of non-judicial resolution of disputes; benefits of litigation).

92. See pp. 1598-1600 \& note 49 supra (inevitability of judicial review).

93. Blanchette v. Connecticut Gen. Ins. Corp., 419 U.S. 102, 138 (1974) ("questions of ripeness" said to involve "the exercise of judicial restraint" for reasons distinct from Article III ripeness considerations).

94. The ripeness doctrine's function in protecting the courts from conflicts whose issues are too inchoate for conventional legal analysis is evident in cases involving anticipatory challenges to official action. Compare United Pub. Workers v. Mitchell, 330 U.S. 75, $89-90$ (1947) (controversy not ripe, where Court could not assess lawfulness of future official action pursuant to an unfamiliar statutory scheme in Hatch Act) with United States Civil Serv. Comm'n v. National Ass'n of Letter Carriers, 413 U.S. 548 (1973) (twenty-five years after United Public Workers, Court able to consider similar challenge to official action under the original legislation). See P. Bator, P. Mishkin, D. Shapiro, \& H. 
for lack of ripeness typically have involved uncertainties about the principals' future activities: prospective official activity that is too contingent to have ascertainable legal consequences cannot give rise to an Article III "case."

The issues for decision in the inter-agency lawsuit, however, involve no such contingencies. When claimants to regulatory jurisdiction enter court armed with conflicting interpretations of the relevant statutes, the issue is "pure" in that it requires declaration of legislative intent but no assessment of the legal effect of the parties' past or contingent conduct. ${ }^{96}$ The action cannot fail for lack of concreteness or specificity in the statutes and other instruments; confusion about the instruments' meaning is, after all, the essence of the conflict. The novelty of a complex statutory scheme, or a lack of judicial experience with its functioning, does not make its construction premature. ${ }^{97}$ Nor is the dispute hypothetical, according to cur-

Wechisler, Hart and Wechsler's The Federal Courts and the Federal System (2d ed.) [hereinafter cited as HART \& WeCHSLER] 32 (Supp. 1977) (suggesting that lapse of time and gain in "substantial experience" with challenged legislation help explain change in ripeness of attack on Hatch Act from time of United Public Workers to Letter Carriers). See also Scharpf, Judicial Review and the Political Question: A Functional Analysis, 75 YALE L.J. 517, 531-32 (1966) (court's appraisal of ripeness said to depend upon its assessment of need for factual development in light of legal issues action raises; the more generalized the questions, the less the need for detailed factual development).

95. See note 94 supra (cases challenging criminal statutes); cf. Nash v. Califano, 613 F.2d 10, 14 (2d Cir. 1980) (distinguishing cases "contesting the validity of a penal statute or the policies of a prosecuting authority when [the plaintiff] is neither prosecuted nor threatened with prosecution" from complaint alleging impairment of official functions by other federal activities; sub silentio holding the latter ripe for declaratory judgment).

96. Thus inter-agency jurisdictional disputes, because they turn upon broad problems of statutory construction, put the courts to tasks similar to that in Blanchette v. Connecticut Gen. Ins. Corp., 419 U.S. 102 (1974). The Court adjudged the portions of the Blanchetle case that did not depend upon a then unperformed calculation of share values, but instead involved only application of constitutional standards to the statutory framework Congress had established, to be ripe for adjudication. Similarly, the court in National Automatic Laundry \& Cleaning Council v. Shultz, 443 F.2d 689 (D.C. Cir. 1971), held ripe a challenge to the jurisdiction of the Labor Department to issue certain wage guidelines prior to Departmental promulgation of a wage schedule. After noting the ripeness doctrine's function in ensuring that courts did not "entangl[e] themselves in abstract disagreements over administrative policies," id. at 695 (citing Abbott Laboratories, Inc. v. Gardner, 387 U.S. 136, 148 (1967)), the court concluded:

There is no problem of identifying or refining pertinent facts insofar as the court is called upon to consider the validity of the Administrator's interpretation [of his jurisdiction to regulate plaintiffs]. There is no "record" to be studied or made, for the only record involved on this issue is that established by such materials as the law and its legislative history.

Id. As in Blanchette and National Automatic Laundry \& Cleaning Council, the gencrality of the issues in inter-agency lawsuits vests them with an early maturity.

97. See, e.g., Buckley v. Valeo, 424 U.S. 1, 11-12 (1976) (per curiam) (displaying willingness to construe novel statute); Blanchette v. Connecticut Gen. Ins. Corp., 419 U.S. 102, 142 (1974) (same). 
rent standards for ripeness; the agencies' pleadings amount to affidavits stating the disputants' good-faith intentions to attempt to regulate the controverted subject-matter. ${ }^{98}$

\section{2. "Prudential" Ripeness}

Distinct from the Article III ripeness requirement is the policy urging delay in adjudication when postponement would serve the interests of the public and the litigants. ${ }^{99}$ The prudential ripeness doctrine requires a balancing analysis that almost always will favor adjudication of the administrator's complaint. The question is whether the public interest in efficient use of judicial energies will outweigh the distinct administrative interest in early resolution of a serious intra-branch jurisdictional dispute. ${ }^{100}$

In many cases, the court's alternative to inter-agency litigation will be to wait until the Justice Department has thrown its weight behind one of the executive-branch disputants and an external challenge has arisen.101 Awaiting an external challenge is unlikely to spare the court exertions sufficient to outweigh the public interest in resolution of a legal dispute that has paralyzed implementation of congressional regulation. If the confusion is grave enough to have produced a clash among the federal agencies, it is unlikely that private challengers will omit the issue of regulatory jurisdiction from their attack on the executive branch's ultimate administrative action. ${ }^{102}$ Thus, rarely would the courts be able to avoid addressing

98. Cf. National Automatic Laundry \& Cleaning Council v. Shultz, 443 F.2d 689, 701 (D.C. Cir. 1971) (absent affidavit to rebut it, a presumption of finality attached to agency head's assertion of regulatory jurisdiction).

99. Blanchette v. Connecticut Gen. Ins. Corp., 419 U.S. 102, 138 (1974); Landis v. North Am. Ins. Co., 299 U.S. 248, 256 (1936); cf. Duke Power Co. v. Carolina Environmental Study Group, Inc., 438 U.S. 59, 81-82 (1978) (presupposing analytically distinct constitutional and prudential ripeness requirements).

100. See pp. 1604-08 supra (public interest in inter-agency lawsuits).

101. Insofar as the prudential doctrine aims at conservation of judicial resources, the court should decide the case if delay would place it "in no better position later . . to to confront the validity of [a controverted statute's] provisions." Blanchette v. Connecticut Gen. Ins. Corp., 419 U.S. 102, 145 (1974); see Independent Bankers Ass'n of $\Lambda \mathrm{m}$. v. Heimann, 613 F.2d 1164, 1167 (D.C. Cir. 1979) (if later attempts to assert the disputed power are certain to produce litigation and resolution of legal issues does not require case-by-case factual development, "prompt resolution will eliminate uncertainty and be in the interest of efficient judicial administration"). But cf. Brilmayer, The Jurisprudence of Article III: Perspectives on the "Case or Controversy" Requirement, 93 HARv. L. REv. 297, 315 (1979) (courts should avoid adjudication that would "encroach on the prerogatives of later courts.")

102. The tradition of non-deferential judicial treatment of Justice Department advice resolving intra-branch disputes, see note 26 supra (judicial decisions rejecting Justice Department opinions), would demonstrate to private parties that even if the Justice Department's arbitration had an outcome adverse to their interests, an attack on the internal settlement would stand some chance of rewarding the effort of litigation. 
the jurisdictional issue in inter-agency litigation through dismissal on ripeness grounds.

Some judicial effort might be saved if a delay would clarify the issues for later resolution in an external party's challenge. But in a lawsuit seeking reconciliation of ambiguous or conflicting statutory mandates, a dispute that meets the Article III ripeness test for concreteness is unlikely to attain more clarity through delay. Precisely because the statutes are difficult to interpret, the agencies cannot spend further time and public money on regulation without first entrusting their conflicting claims either to Justice Department arbitration or to the federal courts. ${ }^{\mathbf{1 0 3}}$ Some sector of the national government must respond to the jurisdictional uncertainty by interpreting the statutes. The interpretive effort that the courts are "saved," if they defer to the arbitration process, would be expended instead by the Attorney General. Moreover, agency reliance on the Justice Department's advice would incur substantial risks of ultimate reversal in the courts. ${ }^{10 t}$ For a court to assume the burden of adjudicating a justiciable dispute would, however, spare the Justice Department the same interpretive task and avert the needless risks and delays of arbitration. ${ }^{105}$

\section{The Institutional Setting of the Litigation}

By consolidating the initial intra-branch dispute with the external parties' challenge, adjudication of an inter-agency legal conflict would require judicial performance of tasks frequently undertaken by the President and his law officers. Such an adjustment raises another question concerning justiciability: would judicial resolution of the dispute violate the constitutionally established pattern of institutional specialization among the three branches?

\section{The Substantive Justiciability of the Issues-Political Questions}

A recognized category of non-justiciable disputes are those for which "judicially discoverable and manageable standards"106 are lacking. Implicit in many decisions declining jurisdiction ${ }^{107}$ is a belief

103. Though the federal agencies must routinely commit resources, with or without express Justice Department advice, even though they lack any assurance of ultimate affirmance by the courts, the risks of error on a jurisdictional question are unique. See pp. 1601-02 supra (risks of agency action on questionable statutory basis).

104. See note 26 supra (significant chance of reversal of Justice Department's position).

105. See p. 1600 supra.

106. Baker v. Carr, 369 U.S. 186, 217 (1962).

107. See, e.g., Goldwater v. Carter, 100 S. Ct. 533, 533-36 (1979) (Powell, J.) (labelling 
that courts are ill-equipped to solve social and political problems. ${ }^{108}$ Inter-agency legal disputes concerning regulatory jurisdiction do not, however, test the limit of judicial competence. The traditional model for resolution of intra-branch disputes itself assigns the jurisdictional dispute to the courts when an external party challenges the administrative activity. ${ }^{109}$

\section{Separation of Powers}

The federal courts are expected to enforce specific statutory commitments of regulatory power when reviewing the lawfulness of agency action. ${ }^{110}$ Under the current two-step system, the constitutionally required inquiry into regulatory jurisdiction will occur after the President has spoken through the internal arbitration process; the doctrine of separation of powers does not permit the courts to avoid adjudication simply because the President has spoken. ${ }^{111}$

To suggest that the separation of powers doctrine requires judicial inaction before the President has acted but not after he has done so -that is, to see a difference between inter-agency litigation and later judicial review proceedings-imputes an empty temporal significance

as "not ripe," but otherwise justiciable, complaint deemed by other Justices to be nonjusticiable political question); Warth v. Seldin, 422 U.S. 490,520 (1975) (Brennan, J., dissenting) (attributing majority's decision to dismiss complaint for lack of standing to case's "grave sociological and political ramifications").

108. Whether a case involves a political question is "essentially a function of the separation of powers." Baker v. Carr, 369 U.S. 186, 217 (1962); see, e.g., Goldwater v. Carter, 444 U.S. 996, 1002-06 (1979) (Rehnquist, J.) (holding challenge to conduct of foreign policy presented "political question"); Orlando v. Laird, 443 F.2d 1039, 1043 (2d Cir. 1971) (dismissing as political question claim concerning warmaking power).

109. See p. 1600 supra (continuity of juriselictional issues in two-step model). It is noteworthy that in United States v. Nixon, 418 U.S. 683 (1974), the Court found the Special Prosecutor's claims to be "'of a type which are traditionally justiciable." Id. at 697 (quoting United States v. ICC, 337 U.S. 426, 430 (1949) (suit by War Department against Commission)). The Court had previously noted, without approving or disapproving, a characterization of the issues by the President's counsel "as essentially a 'jurisdictional" dispute ... in determining what evidence is to be used in a given criminal case." Id. at 693. Evidently the Court did not think that whatever "jurisdictional" quality the issues possessed deprived them of their "traditionally justiciable" character.

110. See National Automatic Laundry \& Cleaning Council v. Shultz, 443 F.2d 689, 695 (D.C. Cir. 1971) ("In our overall pattern of government the judicial branch has the function of requiring the executive (or administrative) branch to stay within the limits prescribed by the legislative branch."); cf. United States v. Nixon, 418 U.S. 683, 703 (1974) (although constitutional views of President are entitled to deference, "[m]any decisions of this Court, however, have unequivocally reaffirmed . . . that '[i]t is emphatically the province and duty of the judicial department to say what the law is.") (quoting Marbury v. Madison, 5 U.S. (1 Cranch) 137, 177 (1803)); Powell v. McCormack, 395 U.S. 486, 549 (1969) (judicial task extends to interpretation of Constitution even at variance with congressional position).

111. Cf. United States v. Nixon, 418 U.S. 683, 697 (1974) (deciding merits of presidential interpretation of "the applicable law and regulation"). 
to the doctrine. Far from serving any institutional purpose, such an approach actually would prejudice an important value reflected in the separation of powers doctrine. One reason for the courts to deal sensitively with coordinate powers is to avoid "the potentiality of embarrassment from multifarious pronouncements by various departments on one question." 112 An early judicial resolution of the jurisdictional dispute, rather than forebearance until the President has spoken, would avoid such embarrassment.

\section{Finality of Judgment}

A third inter-branch limitation on federal judicial power requires that a judicial order have "finality." 113 If, after the courts have spoken, a coordinate political branch could act to nullify the judicial resolution, any exercise of Article III power would be inappropriate: the judicial decree would not adjust the legal positions of the litigants but would only provide advice to the other branches as they developed their own solution to a controversy. ${ }^{114}$ The finality doctrine does not, however, permit the courts to decline jurisdiction because of fear that the executive or legislative branches might fail to obey their orders. ${ }^{115}$

In an inter-agency dispute, a court would be entitled to assume that the President will not attempt to frustrate the court's mandate by directing the losing administrator to take jurisdiction and the victor to defer. ${ }^{110}$ Far more likely is the possibility that Congress might "repeal" a court's interpretation of the controverted statute through amendment. Yet such a congressional response would not violate the norm of judicial finality. Congress routinely adjusts its legislation in

112. Baker v. Carr, 369 U.S. 186, 217 (1962). See also id. at 211 ("Deciding . . whether action of ... [another] branch exceeds whatever authority has been committed [by the Constitution] is itself a delicate exercise in constitutional interpretation, and is a responsibility of this Court as ultimate interpreter of the Constitution.")

113. The finality requirement has two inter-branch components: the institutional setting of the judicial action must not expose the decree to "revision" by the executive branch, see HART \& WECHSLER, supra note 94, at 91-92, or by the Congress, id. at 98-102.

114. Chicago \& S. Air Lines v. Waterman S.S. Co., 333 U.S. 103, 113-14 (1948) (refusing to review administrative order that President could have disapproved after judicial decision affirming it).

115. See Powell v. McCormack, 395 U.S. 486, 549 (1969) (alleged conflict in constitutional interpretation among branches cannot justify courts avoiding constitutional responsibility); accord, Blanchette v. Connecticut Gen. Ins. Corp., 419 U.S. 102, 149 n.35 (1974); Glidden Co. v. Zdanok, 370 U.S. 530, 571 (1962) (Harlan, J.); Nixon v. Sirica, 487 F.2d 700, 711-12 (D.C. Cir. 1973).

116. If agencies did take action violating the court's declaratory order, private parties might (1) obtain mandamus pursuant to 28 U.S.C. $\$ 1361$ (1976) to enforce it, or (2) await other agency actions that would make the unlawful assumption or deferral of regulatory jurisdiction subject to more conventional review proceedings. 
reaction to judicial decisions. ${ }^{117}$ Adjudication of the issues in an inter-agency suit would thus be no less "final" than a judgment on the same questions in the conventional context of an attack on government regulation by external parties.

\section{Conclusion}

Conflicts about the regulatory jurisdiction of executive-branch agencies are inevitable. The legitimacy of both presidential and judicial participation in the resolution of uncertainties about the agencies' power is not subject to serious debate today. Yet the current approach to settling inter-agency jurisdictional conflicts assigns the courts ultimate responsibility for interpretation of statutes, but requires them to await formulation of a single executive-branch answer to the issues they must decide. That approach can involve a paralysis of the administrative process not required by the federal constitutional design. Placing a limited power to litigate in the hands of the administrators would simplify resolution of the executive branch's legal conflicts without straining traditional limits on judicial competence.

117. A court might find it prudent to abstain from adjudication of a controversy if it were probable that the uncertainty would be resolved by congressional amendment of the relevant statutes. Cf. Reuss v. Balles, 584 F.2d 461, 468 (D.C. Cir.), cert. denied, 439 U.S. 997 (1978) (basing denial of standing in part upon possibility of redress of plaintiff's grievance through amendment of challenged legislation). 